\title{
PENGARUH PENAMBAHAN PROBIOTIK Rhizopus oligosporus SEBAGAI ADITIF PAKAN TERHADAP PENAMPILAN PRODUKSI BURUNG PUYUH (Coturnix coturnix japonica)
}

\author{
Effect of Addition of Rhizopus oligosporus Probiotic as Feed Additive on Quail \\ (Coturnix coturnix japonica) Production Performances \\ Danial Mukhtar Husada ${ }^{1)}$, Eko Widodo ${ }^{2)}$, dan Osfar Sjofjan ${ }^{2)}$ \\ ${ }^{1)}$ Mahasiswa Fakultas Peternakan, Universitas Brawijaya, Malang-65145, Indonesia \\ ${ }^{2)}$ Dosen Minat Nutrisi dan Makanan Ternak, Fakultas Peternakan, Universitas Brawijaya, Malang-65145, \\ Indonesia \\ Email: eko.widodo@ub.ac.id
}

\begin{abstract}
ABSTRAK
Penelitian ini bertujuan untuk mengetahui pengaruh penambahan probiotik Rhizopus oligosporus sebagai aditif pakan pada penampilan produksi burung puyuh (Coturnix coturnix japonica). Penelitian ini menggunakan burung puyuh petelur sebanyak 250 ekor umur 90 hari yangsetap petak terdiri dari 10 ekor. Materi yang digunakan yaitu pakan komersial dan probiotik Rhizopus oligosporus. Pakan perlakuan yang digunakan yaitu $\mathrm{PO}=$ pakan basal tanpa probiotik, $P 1=$ pakan basal $+0,4 \%$ probiotik Rhizopus oligosporus, $P 2=$ pakan basal $+0,5 \%$ probiotik Rhizopus oligosporus, $P 3=$ Pakan basal $+0,6 \%$ probiotik Rhizopus oligosporus, P4= Pakan basal $+0,7 \%$ probiotik Rhizopus oligosporus.Metode penelitian yang digunakan adalah metode percobaan lapang dengan menggunakan Rancangan Acak Lengkap (RAL) yang terdiri 5 perlakuan dan 5 ulangan. Variabel yang diamati meliputi konsumsi pakan, HDP (Hen Day Production), egg mass, konversi pakan, dan IOFC (Income Over Feed Cost). Data ditabulasikan ke dalam Microsoft Excel dan menggunakan analisis ANOVA dari Rancangan Acak Lengkap. Apabila diperoleh hasil yang berbeda nyata antar perlakuan maka dilanjutkan dengan Uji Jarak Berganda Duncan's. Hasil penelitian menunjukkan bahwa penambahan probiotik Rhizopus oligosporus sebagai aditif pakan memberikan perbedaan pengaruh yang tidak nyata $(P>0,05)$ terhadap konsumsi pakan tetapi memberikan perbedaan pengaruh yang nyata $(P<0,05)$ terhadap HDP, egg mass, konversi pakan dan IOFC. Kesimpulan dari penelitian ini adalah penambahan probiotik Rhizopus oligosporus sebagai aditif pakan burung puyuh tidak dapat memperbaiki penampilan produksi yang meliputi konsumsi pakan, HDP, egg mass, konversi pakan dan IOFC. Saran dari penelitian ini yaitu perlu dilakukan penelitian lebih lanjut mengenai penambahan probiotik Rhizopus oligosporus dengan menggunakan pakan basal self mixing.
\end{abstract}

Kata kunci: Burung puyuh; penampilan produksi; Probiotik;Rhizopus oligosporus

How to Cite :

Husada, D. M., Widodo, E., \& Sjofjan, O. (2018). Pengaruh Penambahan Probiotik Rhizopus Oligosporus Sebagai Aditif Pakan Terhadap Penampilan Produksi Burung Puyuh (Coturnix coturnix japonica) . Jurnal Nutrisi Ternak Tropis, 1 (1) 18- 23
*Corresponding author:

Danial Mukhtar Husada

Email : eko.widodo@ub.ac.id

Faculty of Animal Science, Brawijaya University, Veteran Street, Malang, East Java, Indonesia. 65145 


\section{ABSTRACT}

The purpose of this research was to find out the effect of addition of Rhizopus oligosporusprobiotic as feed additive on quail (Coturnix coturnix japonica) production performances. This research used 250 female quails 90 days old each unit consisted of 10 quails. The material used were commercial feed and Rhizopus oligosporus probiotic. The feed treatments given namely $T 0=$ basal feed no Rhizopus oligosporus probiotic, $T 1=$ basal feed $+0.4 \%$ Rhizopus oligosporus probiotic, T2= basal feed $+0.5 \%$ Rhizopus oligosporus probiotic, T3= basal feed $+0.6 \%$ Rhizopus oligosporus probiotic, $T 4=$ basal feed $+0.7 \%$ Rhizopus oligosporus probiotic. The method used in this research was field experimentusing 5 treatments and 5 replications. The variables measured were feed intake, HDP (Hen Day Production), egg mass, feed conversion, and IOFC (Income Over Feed Cost). Data were tabulated in Microsoft Excel and analyzed using ANOVA of Completely Randomized Design (CRD). If there were significant effect among the treatments therefore it was tested using Duncan's Multiple Range Test (DMRT).The result showed that addition of Rhizopus oligosporus probiotic as feed additive had no significant effect $(P>0.05)$ on feed intake yet gave significant effect $(P<0.05)$ on HDP, egg mass, feed conversion, and IOFC. The conclusion of this research was the addition of Rhizopus oligosporus probiotic as feed additive did not improve the production performance including feed intake, HDP, egg mass, feed conversion and IOFC. The suggestion of this research was needed further research on addition of Rhizopus oligosporus probiotic using self-mixing feed.

Keywords: Probiotic; production performance; Rhizopus oligosporus; quail.

\section{PENDAHULUAN}

Populasi burung puyuh (Coturnix coturnix japonica) setiap tahunnya mengalami peningkatan yang sangat cepat. Populasi burung puyuh di Indonesia pada tahun 2011 sebanyak 1.809 .631 ekor dan meningkat pada tahun 2015 sebanyak 2.773.679 ekor (Dirjen Peternakan dan Kesehatan Hewan, 2015). Meningkatnya populasi burung puyuh setiap tahunnya diiringi dengan meningkatnya minat dari konsumen akan permintaan daging dan telur dari burung puyuh.

Biaya pakan merupakan faktor terpenting dalam pemeliharaan burung puyuh. Biaya pakan dalam usaha peternakan burung puyuh yaitu mencapai $70 \%$ dari total biaya keseluruhan. Masalah lain yang dihadapi yaitu banyaknya ketergantungan penggunaan antibiotik. Penggunaan antibiotik yang berlebihan akan berdampak pada resistensi bakteri patogen serta dapat menimbulkan residu pada daging dan telur yang dapat membahayakan kesehatan konsumen.
Kapang Rhizopus oligosporusatau yang biasa disebut dengan ragi tempe memiliki sifat proteolitik dan lipolitik. Rhizopus $s p$ mampu menghasilkan enzim ekstraseluler seperti protease, amilase dan lipase yang dapat membantu hodrolisis substrat menjadi lebih sederhana sehingga mudah diserap dalam saluran pencernaan (Pratiwi, Sugiharto dan Yudiarti, 2014). Pencampuran kapang Rhizopus oligosporus dalam pakan ternak dimungkinkan dapat mempengaruhi penampilan burung puyuh petelur. Tujuan penelitian ini adalah untuk mengetahui pengaruh penambahan probiotik Rhizopus oligosporus sebagai aditif pakan terhadap penampilan produksi burung puyuh.

\section{MATERI DAN METODE}

Materi penelitian adalah burung puyuh petelur yang diambil dari peternakan milik Bapak Iskandar di Desa Ampeldento, Kecamatan Karangploso, Kabupaten Malang sebanyak 250 ekor yang berumur 90 hari selama 4 minggu. 
Metode penelitian adalah metode percobaan lapang dengan menggunakan Rancangan Acak Lengkap (RAL) yang terdiri dari 5 perlakuan dan 5 ulangan. Pakan perlakuan yang diberikan yaitu perlakuan $\mathrm{P} 0=$ pakan basal tanpa probiotik Rhizopus oligosporus, $\mathrm{P} 1=$ pakan basal + $0,4 \%$ probiotik Rhizopus oligosporus, $\mathrm{P} 2=$ pakan basal $+0,5 \%$ probiotik Rhizopus oligosporus, $\mathrm{P} 3=$ pakan basal $+0,6 \%$ probiotik Rhizopus oligosporus, $\mathrm{P} 4=$ pakan basal $+0,7 \%$ probiotik Rhizopus oligosporus. Variabel yang diukur adalah konsumsi pakan, HDP (Hen Day Production), egg mass, konversi pakan dan IOFC (Income Over Feed Cost). Analisis data menggunakan ANOVA dari Rancangan Acak Lengkap dan apabila terdapat perbedaan yang nyata dilanjutkan dengan Uji Jarak Berganda Duncan's.

\section{HASIL DAN PEMBAHASAN}

\section{Pengaruh Perlakuan terhadap Konsumsi Pakan}

Data hasil penelitian pengaruh penambahan probiotik Rhizopus oligosporus sebagai aditif pakan pada penampilan produksi burung puyuh dapat dilihat pada Tabel 1 .

Tabel 1. Pengaruh perlakuan terhadap konsumsi pakan (g/ekor/hari), HDP (\%), egg mass (g/ekor/hari),konversi pakan dan IOFC (Rp/ekor/hari).

\begin{tabular}{cccccc}
\hline \multirow{2}{*}{ Perlakuan } & \multicolumn{5}{c}{ Variabel yang diamati } \\
\cline { 2 - 6 } & $\begin{array}{c}\text { Konsumsi } \\
\text { Pakan }\end{array}$ & HDP & Egg Mass & $\begin{array}{c}\text { Konversi } \\
\text { Pakan }\end{array}$ & IOFC \\
\hline P0 & $25,32 \pm 0,37$ & $89,14 \pm 6,52^{\mathrm{b}}$ & $7,92 \pm 0,69^{\mathrm{b}}$ & $3,23 \pm 0,28^{\mathrm{a}}$ & $36,24 \pm 16,40^{\mathrm{b}}$ \\
P1 & $24,68 \pm 0,77$ & $82,00 \pm 10,72^{\mathrm{ab}}$ & $7,30 \pm 0,75^{\mathrm{ab}}$ & $3,43 \pm 0,34^{\mathrm{a}}$ & $25,44 \pm 14,68^{\mathrm{ab}}$ \\
P2 & $24,58 \pm 0,32$ & $87,14 \pm 6,85^{\mathrm{b}}$ & $7,60 \pm 0,47^{\mathrm{b}}$ & $3,28 \pm 0,22^{\mathrm{a}}$ & $32,90 \pm 11,68^{\mathrm{b}}$ \\
P3 & $24,53 \pm 0,38$ & $80,57 \pm 8,24^{\mathrm{ab}}$ & $7,17 \pm 0,65^{\mathrm{ab}}$ & $3,47 \pm 0,28^{\mathrm{ab}}$ & $22,92 \pm 14,77^{\mathrm{ab}}$ \\
P4 & $24,25 \pm 0,79$ & $74,29 \pm 2,26^{\mathrm{a}}$ & $6,56 \pm 0,18^{\mathrm{a}}$ & $3,73 \pm 0,09^{\mathrm{b}}$ & $9,79 \pm 3,53^{\mathrm{a}}$ \\
\hline
\end{tabular}

Hasil analisis statistik pada Tabel 1 menunjukkan bahwa penggunaan Rhizopus oligosporus dalam pakan memberikan perbedaan pengaruh yang tidaknyata $(\mathrm{P}>0,05)$ terhadap konsumsi pakan burung puyuh. Hal ini diduga karena kandungan gross energy pakan pada setiap perlakuan sama sehingga menghasilkan konsumsi pakan yang juga relatif sama. Pakan yang digunakan pada setiap perlakuan mengandung gross energy sebesar 4198,01 $\mathrm{Kkal} / \mathrm{kg}$ dengan protein kasar pakan sebesar 21,76 \% sesuai dengan yang disarankan oleh SNI (2006) yaitu kandungan protein minimal $17 \%$. NRC (1994) menambahkan kandungan tingkat gross energy dan serat kasar dalam pakan akan menentukan jumlah pakan yang dikonsumsi. Hal ini sesuai dengan pendapat Rose (2005) bahwa apabila kandungan energi dalam pakan tinggi, dapat menyebabkan konsumsi pakan menurun dan sebaliknya apabila kandungan energi dalam pakan rendah maka konsumsi pakan akan meningkat. Pernyataan ini juga diperkuat oleh pernyataan Tillman, dkk. (1991) bahwa unggas mengonsumsi pakan untuk memenuhi kebutuhan energi. Jika persentase protein yang tetap terdapat dalam semua pakan, maka pakan yang berkonsentrasi energi metabolis tinggi akan menyediakan protein yang cenderung kurang dalam tubuh unggas karena rendahnya jumlah pakan yang dikonsumsi. Sebaliknya, apabila energi kurang maka unggas akan mengonsumsi pakan untuk mendapatkan energi lebih banyak yang berakibat pada konsumsi protein yang berlebihan.

\section{Pengaruh Perlakuan terhadapHDP (Hen Day Production)}

Berdasarkan data hasil penelitian yang disajikan pada Tabel 1 dapat dilihat 
bahwa penambahan probiotik Rhizopus oligosporus sebagai aditif pakan memberikan perbedaan pengaruh yang nyata $(\mathrm{P}<0,05)$ terhadap HDP atau produksi telur harian. Tabel 1. menunjukkan bahwa terjadi penurunan produksi telur harian dengan adanya penambahan probiotik Rhizopus oligosporus. Produksi tertinggi yaitu pada perlakuan P0 dengan rataan $89,14 \pm 6,52 \%$ dan produksi terendah yaitu pada perlakuan P4 dengan rataan $74,29 \pm 2,26 \%$. Penurunan produksi ini diduga karena jumlah koloni atau TPC (Total Plate Count) probiotik Rhizopus oligosporus berada pada jumlah yang tidak begitu besar yaitu $3,2 \times 10^{6} \mathrm{CFU} / \mathrm{mg}$. Hal tersebut diperkuat oleh pernyataan Svensson (1999) dan Vinderolla,et al. (2000) bahwa probiotik minimal mengandung mikroba sebanyak $10^{6}-10^{8}$ $\mathrm{CFU} / \mathrm{ml}$ atau $10^{8}-10^{10} \mathrm{CFU} / \mathrm{mg}$. Pernyataan tersebut juga diperkuat oleh pernyataan Imaduddin (2013) bahwa tidak terdapat peningkatan pada HDP dan berat telur pada unggas yang ditambahkan nonviable Lactobacillus product. Penurunan produksi ini diduga disebabkan oleh jumlah dari kultur bakteri yang kurang dari $10^{8}$ CFU/mg. Pernyataan tersebut juga diperkuat oleh pernyataan Sjofjan (2001), Kompiang (2000) dan Suherman (2015) bahwa dengan penambahan kultur probiotik Lactobacillus dengan jumlah bakteri $10^{8}$ $\mathrm{CFU} / \mathrm{mg}$ dapat meningkatkan produksi telur harian unggas petelur.

\section{Pengaruh Perlakuan terhadap Egg Mass}

Hasil analisis statistik pada Tabel 1 menunjukkan bahwa penggunaan Rhizopus oligosporus dalam pakan memberikan perbedaan pengaruh yang nyata $(\mathrm{P}<0,05)$ terhadap egg mass burung puyuh. Hal ini diduga karena Rhizopus oligosporus mampu menghasilkan enzim fitase yang berfungsi memecah komponen makro menjadi komponen mikro sehingga membuat pakan basal lebih mudah dicerna dan nutrisinya lebih mudah diserap oleh ternak. Pernyataan tersebut diperkuat oleh pernyataan Jennessen, et al. (2008) bahwa
Rhizopus oligosporus dimanfaatkan dalam pembuatan tempe dari proses fermentasi kacang kedelai, karena Rhizopus oligosporus mampu menghasilkan enzim fitase yang memecah fitat membuat komponen makro pada kedelai dipecah menjadi komponen mikro sehingga tempe lebih mudah dicerna dan nutrisinya lebih mudah terserap tubuh. Hal tersebut juga diperkuat oleh pernyataan North and Bell (1990) bahwa Rhizopus oligosporus juga mensintesa enzim lipase, poligalakturonase, endoselulase, xilanase, arabinase, fitase, dan rhizopus carboksil proteinase. Enzimenzim yang disintesis oleh Rhizopus oligosporus diharapkan mampu meningkatkan efisiensi pakan sehingga dapat meningkatkan produksi burung puyuh. Pernyataan tersebut juga diperkuat oleh pernyataan Belewu andSam (2010) bahwa fermentasi bungkil biji jarak menggunakan Rhizopus oligosporus dapat menurunkan berbagai racun dan anti nutrisi, yaitu inhibitor tripsin, curcin, saponin, asam fitat dan phorbolester, sehingga diharapkan mampu meningkatkan nilai nutrisinya.

\section{Pengaruh Perlakuan terhadap Konversi Pakan}

Hasil analisis statistik pada Tabel 1 menunjukkan bahwa penggunaan Rhizopus oligosporus dalam pakan memberikan perbedaan pengaruh yang nyata $(\mathrm{P}<0,05)$ terhadap konversi pakan burung puyuh. Nilai konversi pakan tertinggi pada perlakuan P4 (0,7\% Rhizopus oligosporus) dengan nilai rataan 3,73 $\pm 0,09$ dibandingkan perlakuan lainnya. Hal ini menunjukkan bahwa penggunaanprobiotik Rhizopus oligosporus dengan penambahan 0,7\% belummampu memperbaiki daya cerna dan konsumsi pakan sehingga menghasilkan berat telur yang kurang baik. Pernyataan tersebut diperkuat oleh pernyataan North andBell (1990) bahwa konsumsi pakan dan berat telur merupakan dua faktor yang menentukan tinggi rendahnya konversi pakan, jika dua faktor tersebut dalam keadaan seimbang maka akan diperoleh 
konversi yang lebih baik, sebaliknya apabila konsumsi pakan dan berat telur dalam keadaan kurang seimbang akan menyebabkan konversi yang kurang baik. Besarnya angka konversi pakan tergantung pada banyaknya pakan yang dikonsumsi dibagi dengan berat telur yang dihasilkan. Hal tersebut diperkuat oleh pernyataan Wahju (2004) bahwa angka konversi pakan yang semakin tinggi membuktikan pakan semakin tidak efisien, sebaliknya apabila konversi pakan semakin rendah membuktikan pakan semakin efisien.

\section{Pengaruh Perlakuan terhadap IOFC (Income Over Feed Cost)}

Hasil analisis statistik pada Tabel 1. menunjukkan bahwa penggunaan Rhizopus oligosporus dalam pakan memberikan perbedaan pengaruh yang nyata $(\mathrm{P}<0,05)$ terhadap IOFC burung puyuh. Nilai IOFC berbeda nyata diduga karena meskipun konsumsi pakan pada setiap perlakuan relatif sama tetapi rataan produksi telur harian pada setiap perlakuan berbeda, sehingga apabila dihitung total penjualan telur dikurangi dengan biaya pakan maka perlakuan HDP tinggi cenderung menghasilkan nilai IOFC yang tinggi pula. Pernyataan tersebut diperkuat oleh pernyataan Widjastuti dan Eadarg (2008) bahwa konsumsi pakan yang relatif sama dapat menyebabkan biaya yang dikeluarkan untuk pembelian pakan juga dalam kisaran yang sama, sedangkan produksi telur memiliki kisaran yang berbeda, sehingga apabila dihitung nilai pendapatan dari total penjualan telur dikurangi biaya pakan, maka HDP (Hen Day Production) yang lebih tinggi cenderung meningkatkan nilai IOFC. Efisiensi pakan juga menentukan biaya pakan, semakin tinggi nilai efisiensi pakan akan menurunkan biaya pakan sehingga dapat memaksimalkan keuntungan. Hal tersebut diperkuat oleh pernyataan Prawirokusumo (1994) bahwa IOFC (Income Over Feed Cost) dipengaruhi oleh besarnya penerimaan dan biaya pakan yang dikeluarkan selama penelitian.

\section{KESIMPULAN}

Penambahan probiotik Rhizopus oligosporus sebagai aditif pakan burung puyuh tidak dapat memperbaiki penampilan produksi yang meliputi konsumsi pakan, HDP, egg mass, konversi pakan dan IOFC. Saran yang dapat diberikan adalah perlu dilakukan penelitian lebihlanjut mengenai penambahan probiotik Rhizopus oligosporus dengan menggunakan pakan basal self-mixing.

\section{DAFTAR PUSTAKA}

Belewu, M. A., \& Sam, R. (2010). Solid state fermentation of jatropha curcas kernel cake: proximate composition $\&$ antinutritional components. Journal Yeast Fungal Research, 1(3), 44-46.

Direktorat Jenderal Peternakan \& Kesehatan Hewan. (2015). Populasi puyuh menurut provinsi 2011 sampai 2015.

Imaduddin, A., Djunaidi, I., \& Sjofjan, O. (2013). Pengaruh penambahan probiotik dalam air minum terhadap penampilan produksi \& kadar NH3 ekskreta ayam petelur. Universitas Brawijaya Malang.

Jennessen, J., Schnürer, J., Olsson, J., Samson, R. A., \& Dijksterhuis, J. (2008). Morphological characteristics of sporangiospores of the tempe fungus Rhizopus oligosporus differentiate it from other taxa of the R. microsporus group. Mycological Research, 112(5), 547-563. https://doi.org/10.1016/j.mycres.2007 .11 .006

Kompiang, I. (2000). Pengaruh suplementasi kultur Bacillus spp. melalui pakan atau air minum terhadap kinerja ayam petelur. Jurnal Ilmu Ternak \& Veteriner, 5(4), 205209. 
National Research Council. (1994). Nutrient requirements of poultry. Washington, DC: National Academy of Science.

North, M. O., \& Bell, D. (1990). Commercial chicken production manual. (4th ed.). New York: Van Nostrand Reinhold.

Pratiwi, K. D., Sugiharto, S., \& Yudiarti, T. (2016). Pengaruh penambahan probiotik Rhizopus oryzae terhadap total mikroba usus halus \& seka ayam kampung periode grower. Animal Agriculture Journal, 3(3), 483-491.

Prawirokusumo, S. (1994). Ilmu gizi komparatif. Yogyakarta: Badan Penerbitan Fakultas Ekonomi.

Siregar, Z., Supriadi, \& Mirwandhono, E. (2003). Peningkatan mutu bungkil inti sawit melalui fermentasi Rhizopus oligosporus \& suplementasi nopcozime-ii untuk ayam pedaging. Universitas Sumatera Utara Medan.

Sjofjan, O. (2001). Isolasi \& identifikasi mikroflora usus ayam petelur sebagai sumber probiotik. Universitas Brawijaya Malang.

SNI. (2006). Pakan puyuh bertelur (quail layer).

Suherman, A. ., Natsir, M. ., \& Sjofjan, O. (2015). Pengaruh penambahan probiotik Lactobacillus plus bentuk tepung sebagai aditif pakan terhadap penampilan produksi burung puyuh. Universitas Brawijaya. Malang.
Svensson, U. (1999). Industrial prespective (Tannock Pr). England: Horizon Scientific Publisher.

Tillman, A. ., Hartadi, H., Reksohadi, S., Prawirokusumo, S., \& Lebdosoekojo, S. (1991). Ilmu makanan ternak dasar. Yogyakarta: Gadjah Mada University Press.

Vinderola, C. ., Bailo, N., \& Reinheimer, J. (2000). Survival of probiotic microflora in Argentinian yoghurts during refrigerated storage. Food Research International, 33(2), 97102. https://doi.org/10.1016/S09639969(00)00011-9

Wahju, J. (2004). Ilmu nutrisi unggas. Yogyakarta: Gadjah Mada University Press.

Widjastuti, T., \& Endang, S. (2008). Pemanfaatan tepung limbah roti dalam pakan ayam broiler \& implikasinya terhadap performa puyuh petelur pada fase produksi pertama. Jurnal Indonesia Tropical Animal Agriculture, 31(3), 162-168.

Wizna, M., Jamarun, N., \& Zuryani, Y. (2000). Pemanfaatan produk fermentasi biji karet dengan rhizopus oligosporus dalam pakan ayam pedaging. Prosiding Seminar Nasional Teknologi Peternakan \& Veteriner. Pustibang Peternakan Bogor, 296-298. 